\title{
16
}

\section{Death, Lies, and Land Registration}

\author{
SIÔN HUDSON AND BRIAN SLOAN
}

\section{Introduction}

Real property is the most valuable and potentially contentious property owned by many people at the point of death. ${ }^{1}$ The recent debate surrounding the so-called 'dementia tax' highlights the significance of the family home from an inheritance perspective, ${ }^{2}$ as does as the emphasis on the importance of passing it on under the new residence nil rate band legislation for inheritance tax purposes. ${ }^{3}$ More immediately, land formerly (co-)owned by a deceased person may already be a home for surviving family members. ${ }^{4}$ This may create some tensions between testamentary freedom on the one hand, and the notion of 'dynamic' security for the protection of purchasers prioritised by the land registration system on the other.

This chapter analyses the law on dealings with registered land after a registered proprietor has died, alongside relevant Land Registry practice, identifying several potential conceptual and practical problems in the area. Section II discusses the tension between the basic conclusiveness of the register under the Land Registration Act 2002 and the logical impossibility of the dead owning property, the possibility that registered title will not devolve onto personal representatives and the associated risks of fraud. Section III highlights the particular difficulties related to (previous) co-ownership and the position of surviving trustees in light of the personal representative's duty to retain control of estate property until it is distributed to genuinely intended (or mandated) beneficiaries.

The chapter considers whether law and practice are fit for purpose from the perspective of the interests of the now-deceased person, surviving co-owners, estate beneficiaries, personal representatives, practitioners and their professional indemnity insurers, as well as considering the objectives of land registration, including by comparing the treatment of registered land with that of other forms of significant property owned by now-deceased

\footnotetext{
${ }^{1}$ See, eg, B Sloan, Borkowski's Law of Succession, 3rd edn (Oxford, Oxford University Press, 2017) 9.

2 See, eg, B Sloan, "Disregards", Deferred Payment Agreements and the "Dementia Tax" (UK Care Guide Blog, 12 September 2017) available at: https://ukcareguide.co.uk/disregards-deferred-payment-agreements-dementiatax/; B Sloan, 'Charges for Charges: Home Sales under the Care Act 2014' in H Conway and R Hickey (eds), Modern Studies in Property Law, vol 9 (Oxford, Hart Publishing, 2017).

${ }^{3}$ Inheritance Tax Act 1984, s 8D. See, eg, J Brook, 'Testamentary Freedom - Myth or Reality?' [2018] Conv 19.

${ }^{4}$ See, eg, G Morrell, M Barnard and R Legard, The Law of Intestate Succession: Exploring Attitudes among Nontraditional Families: Final Report (London, National Centre for Social Research, 2009) 26.
} 
persons. Section IV makes several tentative suggestions for reform in light of the conceptual difficulties relating to the accuracy of the land register, risks of fraud and threats to testamentary freedom identified.

\section{Dealings with Registered Title Following the Death of a Registered Proprietor}

\section{A. The Dead Owning Property and the Conclusiveness of the Register}

This subsection highlights the conceptual inconsistency between the impossibility of the dead owning property and the basic conclusiveness of the land register.

Blackstone wrote that 'the instant a man ceases to be, he ceases to have any dominion. ${ }^{5}$ It is a matter of logic that a dead person cannot own property, as distinct from her (qualified) ${ }^{6}$ ability to direct what happens to her property on death by making a will while still alive. ${ }^{7}$ Nevertheless, a recently deceased person may still be the registered proprietor of land, and the appearance of her name in the register is treated as conclusive proof that she is the landowner. ${ }^{8}$ Conceptually, neither the basic conclusiveness of the land register, nor the principle of 'title by registration, ${ }^{9}$ nor the existence of statutory owner's powers ${ }^{10}$ can alter the logical fact that the dead cannot own property. This is true notwithstanding the fact that a major purpose of the Land Registration Act 2002 is to ensure that the land register 'provides a decisive attribution of proprietorship' such that '[e]state owners are conclusively identified on the face of an authoritative public record.' ${ }^{11}$ The idea is that 'titles ... derive from the register itself, rather than from the external rules of general property law,'12 such that the Land Registrar possesses a 'metaphorical "Midas Touch". ${ }^{13}$ This conceptual inconsistency contributes to what Goymour has called the 'myth' of 'title by registration.. ${ }^{14}$

When a person dies, her property will devolve onto her personal representative(s) under the Administration of Estates Act 1925, ${ }^{15}$ executors in the case of testate succession and

\footnotetext{
${ }^{5}$ W Blackstone, Commentaries on the Laws of England (1765-69), Book II, ch 1, 10. cf, eg, R Paisley, 'The Effect of Death in the Context of the Law of Succession' (Queen's University Belfast School of Law Seminar, Belfast, 1 March 2013) available at: https://www.youtube.com/watch?v=7EVDRsqxHcE.

${ }^{6}$ See, in particular, the Inheritance (Provision for Family and Dependants) Act 1975.

${ }^{7}$ See also R Probert, 'Disquieting Thoughts: Who Will Benefit When We Are Gone?' in B Häcker and C Mitchell (eds), Current Issues in Succession Law (Oxford, Hart Publishing, 2016) 31.

${ }^{8}$ Land Registration Act 2002, s 58.

${ }^{9} \mathrm{HM}$ Land Registry and Law Commission, Land Registration for the Twenty-First Century: A Conveyancing Revolution (Law Com No 254, 1998) [10.43].

${ }^{10}$ Land Registration Act 2002, s 23; cfs 24 (b); see, generally, S Watterson and A Goymour, 'A Tale of Three Promises: (3) The Empowerment Promise' in A Goymour, S Watterson and M Dixon (eds), New Perspectives on Land Registration: Contemporary Problems and Solutions (Oxford, Hart Publishing, 2018).

${ }^{11} \mathrm{~K}$ Gray and SF Gray, Elements of Land Law, 5th edn (Oxford, Oxford University Press, 2009) [2.2.5].

${ }^{12}$ A Goymour, 'Mistaken Registrations of Land: Exploding the Myth of "Title by Registration"' (2013) 72 CLJ 617,618 .

${ }^{13}$ Watterson and Goymour (n 10 above) 282.

${ }^{14}$ Goymour (n 12 above) See also, eg, Scottish Law Commission, Discussion Paper on Land Registration: Void and Voidable Titles (Discussion Paper No 125, 2004) [2.14].

${ }^{15}$ Administration of Estates Act 1925, ss 1-2.
} 
administrator(s) in the case of (broadly) intestate succession. ${ }^{16}$ Such property in principle includes real property, although the relevant property should be considered the estate in land since a concept of dominium over land has historically been 'alien' to English Law. ${ }^{17}$

There is, however, a difficulty in the case of registered land with the notions that a dead person cannot own property and that legal title to her assets vests in her personal representatives. The difficulty essentially relates to the authority of the register. The basic conclusiveness of the register at any given time does not of course mean that it is static. A major purpose of the system is precisely to aid the transfer of land, even if full electronic conveyancing (allowing simultaneous completion and registration) looks unlikely to materialise in the near future. ${ }^{18}$ The legislation has been described as 'very clearly "transaction driven"', 19 and it has been said that 'registration of title is the cornerstone of land marketability' ${ }^{20}$ Therefore, the 2002 Act allows for alteration of the register for the purposes of 'correcting a mistake', 'bringing the register up to date', 'giving effect to any estate, right or interest excepted from the effect of registration', or 'removing a superfluous entry', ${ }^{21}$ with rectification being a more tightly controlled form of alteration that 'involves the correction of a mistake' and 'prejudicially affects the title of a registered proprietor.'22 The notion of 'bringing the register up to date' in the context of the death of a registered proprietor would clearly derive its authority from the general law contained in the Administration of Estates Act 1925.

In the absence of full electronic conveyancing, there will inevitably be a point in time with any transfer of land where the transferee has a right to be registered under the general law but has not yet been entered as the proprietor (and the transferor remains as such). In inter vivos situations, this 'registration gap' produces the difficulty that, as a matter of land registration law, the transferee remains vulnerable to rights created by the transferor before that transferor is removed, ${ }^{23}$ although in a transactional context this vulnerability is tempered by the protection of an Official Search with Priority in favour of the transferee. ${ }^{24}$ Admittedly, the creation of interests during the registration gap is not an option for a deceased person herself, which in some respects makes the succession context less problematic than the inter vivos one.

Despite the conceptual difficulties referred to above, the deceased person will remain on the register as the registered proprietor unless and until removed via alteration, ${ }^{25}$

\footnotetext{
${ }^{16}$ The vesting in the case of the executor occurs at the moment of death (rather than the grant of probate), while for an administrator this does not occur until the grant of letters of administration. In the interim, the estate of an intestate will vest in the Public Trustee, who has a limited role in respect of the property: JR Martin and N Caddick (eds), Williams, Mortimer \& Sunnucks - Executors, Administrators and Probate, 20th edn (London, Sweet \& Maxwell, 2013) [41-01]-[41-08].

${ }^{17}$ Gray and Gray (n 11 above) [2.2.7].

${ }^{18}$ See, eg, Law Commission, Updating the Land Registration Act 2002: A Consultation Paper (Consultation Paper No 227,2016$)$ ch 20.

${ }^{19}$ M Dixon, 'The Reform of Property Law and the Land Registration Act 2002: A Risk Assessment' [2003] Conv $136,136$.

${ }^{20}$ S Cooper, 'Resolving Title Conflicts in Registered Land' (2015) 131 LQR 108, 108.

${ }^{21}$ Land Registration Act 2002, s 65, sch 4, paras 2 and 5.

${ }^{22}$ Land Registration Act 2002, sch 4, para 1.

${ }^{23}$ Stodday Land Ltd v Pye [2016] EWHC 2454 (Ch), [2016] 4 WLR 168.

${ }^{24}$ Land Registration Act 2002, s 70.

${ }^{25}$ See, eg, Barclays Bank PLC v Guy [2008] EWCA Civ 452, [2008] 2 EGLR 74 [9] (Lloyd LJ).
} 
and a personal representative cannot be registered as the proprietor without a grant of probate or letters of administration or a court order appointing the applicant as a personal representative. ${ }^{26}$ It is significant that it can take some time before a grant of representation is obtained after death (albeit that the process is generally quick once an application has been made), ${ }^{27}$ and in 2015 it was said in particular that '[i]ntestate estates can be very slow to be dealt with and there may be some ... estates [relating to deaths after 1995] still unadministered. ${ }^{28}$ This creates particular conceptual difficulties since, unlike in inter vivos conveyancing, it is not merely that the (deceased) former owner ought no longer to be recognised as the legal owner and registered proprietor, but that she cannot be the legal owner under the general law and therefore cannot logically be the registered proprietor either.

To add to the conceptual difficulties and tensions, as the Land Registry explains in its Practice Guide on death:

The personal representative(s) of a deceased sole proprietor of the registered estate, or of a charge or mortgage may, without first being registered themselves in that capacity, deal with that registered estate or charge. They may do this by way of a transfer, or a transfer by way of an assent or appropriation using the appropriate form in either case. ${ }^{29}$

Where this occurs, the personal representative must still produce the same evidence of his entitlement to dispose of the property as if he had been registered, ${ }^{30}$ such that he cannot deal with registered land until the grant of probate or letters of administration. In any event, registered title to the land might not therefore ever be transferred into the names of the personal representatives (such a course of action potentially being considered to involve unnecessary complication and cost), even though the Land Registry's own Practice Guide states that 'the legal estate vests in the personal representatives on the death of the sole proprietor, ${ }^{31}$ although admittedly the Act extends owner's powers to those who are 'entitled to be registered as the proprietor' as well as those who are actually so registered. ${ }^{32}$ A 'transfer on the death ... of an individual proprietor' is specifically excluded from the list of dispositions that are required to be registered (somewhat misleadingly described as registrable dispositions), ${ }^{33}$ such that the 'disposition will operate at law immediately' ${ }^{34}$ Where title is voluntarily transferred to a personal representative, however, the registrar must add 'executor or executrix (or administrator or administratrix) of [name] deceased' to the register entry. ${ }^{35}$

\footnotetext{
${ }^{26}$ Land Registration Rules 2003, SI 2003/1417, r 163(1)-(2).

${ }^{27} \mathrm{See}, \mathrm{eg}, \mathrm{G}$ Owen, 'How Long Does it Take to Issue a Grant of Representation?', Today's Wills \& Probate (31 March 2017), available at: www.todayswillsandprobate.co.uk/news/grant-representation-time-taken/.

${ }^{28} \mathrm{C}$ Sawyer and M Spero, Succession, Wills and Probate, 3rd edn (Abingdon, Routledge, 2015) 167.

${ }^{29}$ HM Land Registry, 'Practice Guide 6: Devolution on the Death of a Registered Proprietor', available at: https:// www.gov.uk/government/publications/devolution-on-the-death-of-a-registered-proprietor/practice-guide6-devolution-on-the-death-of-a-registered-proprietor [2.2]

${ }^{30}$ Land Registration Rules 2003, SI 2003/1417, r 162(1).

${ }^{31}$ Land Registry (n 29 above) [6]. See also Williams, Mortimer \& Sunnucks (n 16 above) [46-03]; Ijacic (executor of the estate of Tripkovic) $v$ Game Developments Ltd [2009] EWLandRA 2008_1081, [2009] EWLandRA 2008_1083 [2] (Deputy Adjudicator Simon Brilliant).

${ }^{32}$ Land Registration Act 2002, s 24(b).

${ }^{33}$ Land Registration Act 2002, s 27(5)(a).

${ }^{34}$ Helman $v$ John Lyon Free Grammar School Keepers and Governors [2014] EWCA Civ 17, [2014] 1 WLR 2451 [21] (Rimer LJ).

${ }^{35}$ Land Registration Rules 2003, SI 2003/1417, r 163(4).
} 
Significantly, the Land Registration Rules specifically provide that:

The registrar shall not be under a duty to investigate the reasons a transfer of registered land by a personal representative of a deceased sole proprietor or last surviving joint proprietor is made nor to consider the contents of the will and, provided the terms of any restriction on the register are complied with, he must assume, whether he knows of the terms of the will or not, that the personal representative is acting correctly and within his powers. ${ }^{36}$

This picture, including the possible delays in obtaining a grant, creates conceptual difficulties which detract from the internal coherence of the law. It also produces a risk of fraud in light of information easily obtainable about a deceased person. ${ }^{37}$

\section{B. The Risk of Fraud}

The situation described in the last subsection creates a possibility that a fraudster could impersonate the deceased person, and transfer the property to a purchaser or mortgage the property to a lender who is unaware of the death. ${ }^{38}$ The Land Registry has said that ' $\left.\mathrm{i}\right] \mathrm{n}$ most instances of fraud it is the purported disponor, rather than the applicant [for registration], who acts fraudulently. ${ }^{39}$ If such impersonation is possible in the context of a person who is still alive, ${ }^{40}$ with one commentator describing it as 'astonishingly simple, ${ }^{41}$ it may be all the easier on death. Even if the purchaser (or a chargee) takes the trouble to inspect the property (as may now be expected in order to secure a full indemnity $)^{42}$ there may be no-one with a proprietary interest in discoverable actual occupation for the purposes of schedule 3, paragraph 2 of the Land Registration Act 2002. It follows that the purchaser may take free of any legitimate interests of those whom the deceased left behind because the interests do not override. ${ }^{43}$ This constitutes a significant interference with the deceased's testamentary freedom.

The theft of a deceased person's identity (or 'ghosting') is 'made possible by a lag between the decedent's death and the date that financial institutions, agencies ... and creditreporting bureaus update their databases. ${ }^{44}$ Identity theft is said to be 'more likely' in situations such as 'where a relationship breaks down', 'where a property is empty or is bought

\footnotetext{
${ }^{36}$ ibid, r 162(2)

${ }^{37}$ S Kirchheimer, 'Protecting the Dead From Identity Theft', AARP Bulletin (2013), available at: www.aarp.org/ money/scams-fraud/info-03-2013/protecting-the-dead-from-identity-theft.html.

${ }^{38}$ See, eg, Ijacic $v$ Game Developments (n 31 above), considered in detail below.

${ }^{39}$ HM Land Registry, 'Practice Guide 67: Evidence of Identity; Conveyancers', available at: https://www.gov.uk/ government/publications/evidence-of-identity-conveyancers/practice-guide-67-evidence-of-identity-conveyancers [2]. See further L Xu, 'Updating Land Registration Law and Practice: Some Lessons From China' Chapter 15 in this volume.

${ }^{40}$ See, eg, Swift 1st Ltd $v$ Chief Land Registrar [2015] EWCA Civ 330, [2015] Ch 602.

${ }^{41}$ S Evans, 'Was Privacy in Land Ownership Such a Bad Thing?' [2017] Conv 357, 358.

${ }^{42} \mathrm{~J}$ Pownall and R Hill, ‘The Land Registry's Perspective: The Practical Challenges of Land Registration' in Goymour (n 10 above) 13.

${ }^{43}$ Land Registration Act 2002, s 29.

${ }^{44} \mathrm{H}$ Davidson, 'Aftermath of the Fight Over Fiduciary Access to Digital Assets: The Revised UFADAA and its Implications for Legislators and Professional Advisors' (2017) 7 Tax Development Journal 58, 61.
} 
to let', 'where the owner is abroad or absent', and 'where the owner is infirm or in a home.45 A situation where a sole registered proprietor has died has something in common with each of these.

If the 'vendor' in these circumstances is represented by a conveyancer, the purchaser is unlikely to take independent steps to verify the vendor's identity, ${ }^{46}$ and the vendor's conveyancer's standard identity checks ${ }^{47}$ may be ineffective if the conveyancer has been duped because the fraudster has the same name (potentially having changed it by deed poll) ${ }^{48}$ as the deceased and claims that (for example) the property being sold was previously rented out, or simply produces to the conveyancer forged identification documents in the name of the deceased. ${ }^{49}$ There are of course occasions where the conveyancer him/herself is a party to the fraud, or may inaccurately appear to be such a party because it is an increasingly common tactic for legitimate law firms to be impersonated by the fraudster, making clever use of headed notepaper and subtle differences in an email address. ${ }^{50}$

A fraudster could also simply transfer the land to himself or an associate for no consideration. The Land Registry will make some attempt to verify identity if a party to the transaction is unrepresented via its ID1 form, involving verification by a solicitor or similar. ${ }^{51}$ That said, however well-versed a busy high-street solicitor may be in taking copies of a person's identification documents, solicitors are not trained to be forgery experts. The unconnected solicitor completing the ID1 form on behalf of an entirely unknown person who walks in apparently possessing all the correct documents can do no more than make the declaration on the ID1 that the person is a true likeness to their photograph, and that they have produced the required documents. ${ }^{52}$ It is also, of course, easy for the fraudster simply to impersonate a legitimate solicitor or conveyancer on the ID1. The risk of fraud therefore remains, and the Law Society claims that ' $[r]$ ecorded incidents of fraud are rising' in relation to real property. ${ }^{53}$ Even though the Land Registry apparently 'prevented frauds on properties valued in excess of $£ 92$ million’ between September 2009 and mid-January 2017, it accepts that 'no system can be 100 per cent fraud-proof' 54 and this will

\footnotetext{
${ }^{45}$ HM Land Registry, 'Public Guide 17: How to Safeguard against Property Fraud' (2008) 1; see now HM Land Registry and Law Society, 'Property and Title Fraud' (2017) 2.

${ }^{46}$ See, eg, S Cooper, 'Seller Fraud and Conveyancers' Liabilities' [2017] Conv 325, 325; S Cooper, 'Lack of Proper Care' in Goymour et al (n 10 above) 193.

${ }^{47}$ Legal Sector Affinity Group, 'Anti-Money Laundering Guidance for the Legal Sector' (2018).

${ }^{48} \mathrm{HM}$ Land Registry and Law Society (n 45 above) 3; Law Commission (n 18 above) [14.94].

${ }^{49}$ In light of the Money Laundering, Terrorist Financing and Transfer of Funds (Information on the Payer) Regulations 2017, SI 692/2017, r 33(5), it is becoming increasingly common in practice to undertake an additional online identity check with a specialist agency in order to corroborate the identification documents produced, a trend which is certainly welcome.

${ }^{50} \mathrm{HM}$ Land Registry and Law Society (n 45 above) [2.1].

${ }^{51}$ HM Land Registry, 'Form: Verify Identity: Citizen (ID1)', available at: www.gov.uk/government/publications/ verify-identity-citizen-id1. See further SR Coveney et al, Ruoff and Roper: Registered Conveyancing (London, Sweet \& Maxwell, 2017) [24.001.02].

${ }^{52}$ Indeed, it is surely true that solicitors or conveyancers are no more qualified to verify somebody's identity documents than any other person: yet the social status of the solicitor gives a false perception of credibility to the documents and the person whose identity is being verified.

${ }^{53}$ Law Society and HM Land Registry, 'Joint Property and Title Fraud Advice Note' (2017) available at: www. lawsociety.org.uk/policy-campaigns/articles/property-and-title-fraud-advice-note/. See, generally, P\&P Property Ltd v Owen White \& Catlin LLP [2018] EWCA Civ 1082, [2018] Lloyd's Rep FC 445.

${ }^{54} \mathrm{~J}$ Prasad, 'High-Profile Case Shows how Property Fraud Can Happen' (HM Land Registry Blog, 16 January 2017) available at: https://hmlandregistry.blog.gov.uk/2017/01/16/high-profile-case-shows-how-propertyfraud-can-happen/.
} 
remain true even if the Law Commission's recommendations in relation to identity checks are implemented. ${ }^{55}$ A Land Registrar and Assistant Land Registrar confirm that ' $\left.\mathrm{i}\right] \mathrm{n}$ the past 10 years, registration fraud has increased considerably', and that this is particularly the case with identity fraud. ${ }^{56}$

An example of the sort of fraud that is possible on the death of a registered proprietor is provided by the Land Registry Adjudicator's decision in Ijacic $v$ Game Developments. ${ }^{57}$ The case is apparently rare in being reported and concerning fraud involving a deceased registered proprietor, but this should not be taken as an indication that more such instances do not occur or that the risks are not significant, even if the reported cases suggest that other forms of fraud are more common. At the time of his death in October 2006, Cetko Tripkovic was the sole registered proprietor of the property in which he lived. Probate was granted to his executor, Mr Ijacic, in 2007, but the executor chose not to become registered as the proprietor. In fact, Mr Tripkovic remained as the registered proprietor at the time of the adjudicator's decision in 2009. The executor instructed a solicitors' firm, MED, to sell the property and account to the beneficiaries under the will, who lived abroad. But in December 2007, a fraudster purporting to be Mr Tripkovic successfully applied to Link Lending (which was in administration at the time of the adjudicator's decision) ${ }^{58}$ for a three-month bridging loan secured on the property. The fraudster declared that the property was unoccupied, giving addresses in Central London and Spain. He purported to supply copies of a page of Mr Tripkovic's passport, his driving licence and his counterpart driving licence. All had been apparently certified by a solicitor (who, it appears, had been struck off by the time of the adjudicator's decision)..$^{59}$ Copies of utility bills stamped by a bank and a bank statement were also supplied, addressed to Mr Tripkovic's property, although the account number was different from the one that the fraudster had given on the mortgage application form. The fraudster managed to execute a mortgage deed in the name of Mr Tripkovic, Link Lending was registered as the proprietor of a charge, and the loan money was advanced to the fraudster's solicitors.

After the approximately $£ 400,000$ loan was not repaid in March 2008, Link Lending exercised its power of sale in favour of Game Developments. Although in January 2008 MED had begun to send a trainee to the property around once a week to check that nothing untoward was happening, the fraud was not discovered until the day after Link Lending and Game Developments had completed the transfer, when estate agents instructed by MED failed to gain access to the property for a viewing because it had been secured by Link Lending's agents. Game Developments did not apply to be registered as the proprietor until April 2008, and following Mr Ijacic's objection was never so registered.

The adjudicator rectified the register by removing the charge in favour of Link Lending, with that decision deemed to take effect before Game Developments' registration application, there being no 'exceptional circumstances' justifying the refusal of rectification in

\footnotetext{
${ }^{55}$ Law Commission, Updating the Land Registration Act 2002 (Law Com No 380, 2018) [14.34]-[14.91].

${ }^{56}$ Pownall and Hill, 'The Land Registry's Perspective: The Practical Challenges of Land Registration' in Goymour (n 10 above) 12.

${ }^{57}$ Ijacic v Game Developments (n 31 above).

${ }^{58}$ Companies House, https://beta.companieshouse.gov.uk/company/01568365/insolvency.

${ }^{59}$ In the Matter of Harilal Susantha Fernando and Purantharan Rajoo, solicitors, findings of the Solicitors Disciplinary Tribunal, No 10078-2008, 28 May 2009.
} 
circumstances where the chargee was not in possession. ${ }^{60}$ Consequently he refused to register Game Developments as the new proprietor and Mr Tripkovic remained. The adjudicator was also confident that Game Developments would receive an indemnity as 'a refusal to register the transfer because the charge no longer existed at the date of Game's original application would be a direct consequence of rectification of the register.61 While all may have been well that ended well, a preventative approach would surely be preferable: things would have been more difficult if the estate beneficiaries had been interested in the property per se or Link Lending had been a purchaser able to go into possession rather than a mere chargee.

Some protection against fraud would be provided if the registered proprietor had entered a Form LL restriction (specifically designed to combat identity theft) while alive, which would prevent a disposition of an estate by the purported registered proprietor 'without a certificate signed by a conveyancer that that conveyancer is satisfied that the person who executed the document submitted for registration as disponor is the same person as the proprietor. ${ }^{6} 2$ But if no such restriction has been entered then the estate beneficiaries are vulnerable, and even then the conveyancer could be in cahoots with, or duped by, a fraudster. This restriction (free of charge if the property is not occupied) ${ }^{63}$ could apparently be entered post-death if the personal representative was registered as proprietor, but it has been seen that this may not happen at all and requires a grant of probate or letters of administration before it can happen. For similar reasons, a restriction in Form C, relating to dispositions by personal representatives other than by way of assent being declared to be in accordance with the will or intestacy rules, ${ }^{64}$ would not solve the difficulty identified here.

The routine use of a restriction Form Q by personal representatives may be a partial solution. This provides:

No disposition [or specify type of disposition] of the

[choose whichever bulleted clause is appropriate]

- registered estate by the proprietor of the registered estate

- registered charge dated [date] referred to above by the proprietor of that registered charge

is to be registered after the death of [name of the current proprietor(s) whose personal representatives' consent will be required] without the written consent of the personal representatives of the deceased. ${ }^{65}$

It is also possible to apply for a restriction that is not in standard form, and the application will be approved if it appears to the registrar that 'the terms of the proposed restriction are reasonable' and that 'applying the proposed restriction' would 'be straightforward', and 'not place an unreasonable burden on him. ${ }^{66} \mathrm{~A}$ standard form restriction would, however, be

\footnotetext{
${ }^{60}$ Land Registration Act 2002, sch 4, para 3(3).

${ }^{61}$ Ijacic v Game Developments (n 31 above) [73] (Deputy Adjudicator Simon Brilliant); Land Registration Act 2002, sch 8.

${ }^{62}$ Land Registration Rules 2003, SI 2003/1417, sch 4.

${ }^{63}$ HM Land Registry, 'Form: Restriction by Owner not Living at Property Request: Registration (RQ)', available at: www.gov.uk/government/publications/restriction-by-owner-not-living-at-property-request-registration-rq.

${ }^{64}$ Land Registration Rules 2003, SI 2003/1417, sch 4.

${ }^{65}$ ibid.

${ }^{66}$ Land Registration Act 2002, s 43(3).
} 
preferable in the sense of being something that could be routinely used in the context of estate administration and would attract a lower fee. ${ }^{67}$

The basic difficulty remains even with a standard form restriction, however. Personal representatives are not expressly listed as '[p] ersons regarded as having a sufficient interest

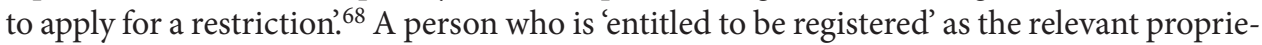
tor is so listed, but a problem might be that a personal representative can prove that he is so entitled only once he has obtained a grant of probate or letters of administration, and we have seen that a vulnerability is present during an intervening period.

The fundamental issue is that the Land Registry may be completely unaware that a registered proprietor has died, at least until a grant of probate or letters of administration is obtained. Ijacic demonstrates that this ignorance can extend beyond the grant if the personal representative takes no relevant action in relation to the property. It is not immediately clear how the Registry would react to receiving a death certificate relating to a registered proprietor without (ie before) a grant of probate or letters of administration. It is to be hoped that such a certificate would not simply be ignored even if the personal representative does not yet have authority to deal with the land, such that a fraudster purporting to be the deceased person could subsequently do so. It must nevertheless be conceded that there is a chance that the risk of fraud might be increased if the Land Registry makes it too obvious that a proprietor has died, which might justify a distinction between information that the Registry holds and that which it publishes. ${ }^{69}$ In section IV of the chapter, the advantages of a new standard form restriction are considered.

Of course, as illustrated by Ijacic, the Land Registration Act 2002 does contain mechanisms for rectification ${ }^{70}$ (demonstrating that indefeasibility of title is not taken to 'extremes') ${ }^{71}$ and indemnity ${ }^{72}$ (albeit that the Law Commission's suggested 'long stop' will to some extent reduce the scope for rectification as against an innocent purchaser). ${ }^{73}$ These mechanisms are logically set up to prejudice those who 'by fraud or lack of proper care caused or substantially contributed to the mistake' (in the case of rectification) ${ }^{74}$ or where loss is suffered wholly or partly as a result of fraud or lack of proper care.$^{75}$ Moreover, Ferris has said that "[a] system of prima facie effective title, subject to possible rectification, is in principle a better system' than one involving '[p]rovisions that deny legal effect to the registration of forged documentation. ${ }^{76}$ But as suggested above, it would be preferable to take more measures to prevent the fraud in the first place rather than to attempt to cure it afterwards, particularly given the onerous consequences of dealing with fraud for estate beneficiaries at an upsetting time (even if they will ultimately be able to reverse its effect), the effect on public finances of the generous nature of the indemnity provisions under the

\footnotetext{
${ }^{67}$ Compare Land Registration Fee Order 2013, SI 2013/3174, sch 3, para 1(1) and para 1(2).

${ }^{68}$ Land Registration Rules 2003, SI 2003/1417, sch 4, r 93; Land Registration Act 2002, s 43(1)(c).

${ }^{69}$ See further Xu (n 39 above).

${ }^{70}$ Land Registration Act 2002, sch 4.

${ }^{71}$ Cooper (n 20 above) 108.

${ }^{72}$ Land Registration Act 2002, sch 8.

${ }^{73}$ Law Commission (n 55 above) ch 13 .

${ }^{74}$ Land Registration Act 2002, sch 4, para 6(2)(a).

${ }^{75} \mathrm{ibid}$, sch 8 , para 5.

${ }^{76}$ G Ferris, 'How Should a System of Registered Title to Property Respond to Fraud and Sharp Practice?' in Conway and Hickey (n 2 above) 224.
} 
$2002 \mathrm{Act}^{77}$ and indeed the cost to solicitors' firms due to professional indemnity insurance claims (often the first port of call when a beneficiary has lost out). Such professional indemnity issues would become particularly acute if, as the Law Commission has recommended, a specific statutory duty of care in relation to identity verification were introduced. ${ }^{78}$

A bank will freeze the account of a deceased person on receipt of a death certificate, usually very early on in the administration of the estate. ${ }^{79}$ It is well established that one of the reasons that there exists a specific body of Land Law is the particular value and importance of land, ${ }^{80}$ and it is strongly arguable that more effort should be made by the land registration system to secure registered land for the benefit of true beneficiaries. In Ijacic, for example, it is noteworthy that the fraud had occurred after the grant of probate and Mr Ijacic and/ or his advisors had probably decided not to involve the Registry in the administration of Mr Tripkovic's estate until they had completed the intended (legitimate) sale. Moreover, it must also be conceded that elements other than the land register and fraudsters themselves contribute to fraud. If the fraudster's solicitor or the lender had acted differently on the facts of that case, the fraud might not have been initially successful.

In addition to the use of standard form restrictions suggested above, one option would be to require the personal representatives to be registered as legal owners in circumstances (at least) where a sole registered proprietor has died, or within a certain period of the death if the land is not otherwise dealt with. This would be consistent with the general rule in the Administration of Estates Act 1925, and its implications will be considered further once co-owned land has been discussed in the next section.

\section{Co-Owned Land}

\section{A. Co-Owned Property on Death}

Particular risks that property will be misappropriated arise where registered land was co-owned (and therefore increasingly likely to be held on trust in the modern era) before death and there remain(s) one or more registered proprietor(s) after a registered proprietor has died. This is especially true in circumstances where the deceased previously held the beneficial title to the property as a tenant in common with a person or people who survive her. It is axiomatic that, where there was such a tenancy in common, the deceased's entitlement passes under the will or intestacy rules rather than accruing to the remaining co-owner(s) by survivorship (as it would in the case of a joint tenancy). ${ }^{81}$ It will be seen, however, that the land registration system might in some circumstances assist the surviving

\footnotetext{
${ }^{77}$ See, eg, M Dixon, Modern Land Law, 11th edn (Abingdon, Routledge, 2018) 37; Law Commission (n 55 above) [14.16]-[14.21].

${ }^{78}$ Law Commission, ibid [14.62]-[14.73].

${ }^{79}$ Law Society, Society of Trust and Estates Practitioner and British Bankers' Association, 'Banking Practices Protocol: Estate Administration' (2016) [15].

${ }^{80} \mathrm{~B}$ McFarlane, The Structure of Property Law (Oxford, Hart Publishing, 2008) [3.1].

${ }^{81}$ See, eg, B McFarlane, N Hopkins and S Nield, Land Law: Text, Cases and Materials, 4th edn (Oxford, Oxford University Press, 2018) 505.
} 
legal co-owner(s) in illegitimately asserting beneficial entitlement to the property where they are not entitled under the will or intestacy rules and someone else is instead, with profound consequences for both testamentary freedom and the rule of law.

That said, it must be conceded that the position with respect to land here reflects that of other property subject to trusts, in that the personal representatives of a now-deceased trustee will not acquire the legal title to the property unless the deceased was herself the sole surviving trustee, ${ }^{82}$ such that there is no need to transfer the legal title where there are surviving co-owners. ${ }^{83}$ As regards jointly held bank accounts, for example, it is well established that, upon a joint account holder's death, the legal title to the chose in action representing the joint account vests entirely in the remaining account holder(s) by virtue of a right of survivorship. ${ }^{84}$ As it was recently put by Lord Briggs in the Privy Council decision in Whitlock $v$ Moree, '[s] urvivorship, that is the devolution of ... legal rights upon the survivor or survivors of joint owners is an inevitable, indeed inherent, aspect of joint legal title 85 (albeit that 'joint tenancy ... is only one of numerous ways in which property may be co-owned beneficially'). ${ }^{86}$ This creates a tension with the general principle that the legal title to the deceased's assets vests in the personal representatives on death, and the duties that the personal representatives owe to the estate beneficiaries in circumstances where the deceased was also a trust beneficiary, but not one unique to land. Lord Briggs and the others in the majority in Whitlock were anxious that essentially the same principles be applied to co-ownership regardless of the type of property involved, ${ }^{87}$ although in dissent Lord Canwath expressed concern about this approach. ${ }^{88}$

\section{B. Tenancy in Common and Restrictions}

While restrictions are in principle designed to protect those beneficially entitled to land who are not on the legal title, this sub-section will demonstrate that they are not always able to perform this function where a registered proprietor dies. Where two or more persons are the registered proprietors of an estate in land, the registrar will be obliged to enter a Form A restriction unless the registrar is informed that the proprietors are trustees for themselves as beneficial joint tenants, or that they are being registered in their capacity as personal representatives. ${ }^{89}$ The entry of this restriction will therefore occur inter alia in circumstances where a tenancy in common is intended and the Land Registry has not been told otherwise, and the restriction's purpose is to ensure that beneficial interests are

\footnotetext{
${ }^{82}$ Trustee Act 1925, s 18.

${ }^{83}$ Land Registration Act 2002, s 27(5)(a).

${ }^{84}$ EP Ellinger, E Lomnicka, and C Hare, Ellinger's Modern Banking Law, 5th edn (Oxford, Oxford University Press, 2011) 324, implicitly approved in Whitlock v Moree [2017] UKPC 44 [60] (Lord Carnwarth, dissenting).

${ }^{85}$ Whitlock $v$ Moree (ibid) [21].

${ }^{86}$ ibid [22].

${ }^{87}$ ibid [26].

88 ibid [55].

${ }^{89}$ Land Registration Act 2002, s 44; Land Registration Rules 2003, SI 2003/1417, r 95; HM Land Registry, 'Practice Guide 24: Private Trusts of Land', available at: www.gov.uk/government/publications/private-trusts-of-land/ practice-guide-24-private-trusts-of-land [1.3]; Ruoff and Roper (n 51 above) [37.007]; Megarry \& Wade: The Law of Real Property, 8th edn (London, Sweet \& Maxwell, 2012) [13-053].
} 
overreached on a purchase or charge ${ }^{90}$ meaning that the purchaser or chargee will take free of any beneficial interests even if their holders would otherwise have had an overriding interest under schedule 3, paragraph 2 of the Land Registration Act. ${ }^{91}$ The restriction provides: 'No disposition by a sole proprietor of the registered estate (except a trust corporation) under which capital money arises is to be registered except under an order of the Court. ${ }^{\text {'92 }}$

Significantly for present purposes, a Form A restriction 'will be cancelled automatically ... when a transfer which overreaches any interests under a trust is registered. ${ }^{93}$ Such cancellation would therefore occur straightforwardly following a death where there is a disposition by two or more surviving trustees (even if not all conveyancers will seek to rely on such overreaching), potentially prejudicing beneficiaries under the deceased's will or the intestacy rules who find their interests overreached. It could be said that this is a straightforward operation of the Act in a manner that reflects the 'curtain principle ${ }^{94}$ and protects 'dynamic' security (ie when the property moves to the ownership of an innocent purchaser) ${ }^{95}$ as intended. ${ }^{96}$ Such purchaser protection has been described as 'the very foundation of land registration' according to the orthodox point of view. ${ }^{97}$ Significantly, the Law Commission concluded in its recently completed project on land registration that 'given the curtain principle ..., the existing mechanisms for the protection of beneficial interests under trusts are sufficient and ... no further protection is appropriate. ${ }^{98}$ That said, the distinction between dynamic and static security (ie protecting those people with existing interests in the property from being deprived of those interests against their will) ${ }^{99}$ is arguably less clear-cut with succession than in the inter vivos context because, while the surviving joint tenant or estate beneficiary is not a purchaser per se, the legal and beneficial ownership of the land must inevitably move (or change) on death, and it could be seen as an important function of the land registration system to ensure that testamentary freedom, or alternatively the intestacy rules, are properly respected.

The current position does not necessarily deny a remedy to a wronged heir where overreaching validly occurs, but leaves the deceased's heirs to pursue proprietary remedies in respect of the sale proceeds and personal remedies for breach of trust where appropriate. ${ }^{100}$ This risk of such a transaction taking place without the involvement of the deceased's executor, however, is perhaps difficult to square with the executor's duties to get in, manage and distribute the property according to the terms of the will, ${ }^{101}$ particularly where the purpose of the will was to give the beneficiary an interest in the home per se. In this respect,

\footnotetext{
${ }^{90}$ Law of Property Act 1925, ss 2, 27(2).

${ }^{91}$ City of London Building Society v Flegg [1988] AC 54 (HL).

${ }^{92}$ Land Registration Rules 2003, SI 2003/1417, sch 4.

${ }^{93}$ HM Land Registry (n 29 above) [6].

${ }^{94}$ See, eg, TBF Ruoff, 'An Englishman Looks at the Torrens system: Part II - Simplicity and the Curtain Principle' (1952) 26 Australian Law Journal 162.

${ }^{95}$ E Cooke, The New Law of Land Registration (Oxford, Hart Publishing, 2003) 100.

${ }^{96} \mathrm{See}, \mathrm{eg}$, Law Commission (n 18 above) [10.43].

${ }^{97}$ Cooper (n 20 above) 108. cf, eg, HSBC Bank Plc v Dyche [2009] EWHC 2954 (Ch), [2010] BPIR 138.

${ }^{98}$ Law Commission (n 18 above) [10.47].

${ }^{99}$ Cooke (n 95 above) 100.

${ }^{100}$ See, eg, G Virgo, Principles of Equity and Trusts, 3rd edn (Oxford, Oxford University Press, 2018) Part VIII.

${ }^{101}$ Administration of Estates Act 1925, s 25; see, eg, B Sloan, Borkowski's Law of Succession (n 1 above) ch 11.
} 
it is worth noting Owen and Cahill's claim in relation to overreaching that 'in 1925 the legislature was not trying to capture any features concerning the use of property primarily as a home.'.102

The current approach to trust property once a death occurs reflects a distinctly formalistic and administrative position. Whatever protection is usually provided by conveyancers, the Land Registry is effectively permitted to ignore the fact that a Form A restriction essentially signals a tenancy in common rather than a joint tenancy, and the substantive law implications of that, as long as overreaching occurs, (ie the correct number of trustees are selling the property). Of course, the remaining co-owners may be beneficiaries under the will or the intestacy rules, but in other circumstances the very purpose of the creation of a tenancy in common will have been to give the deceased's share by her will to people who are not existing co-owners. Yet the land registration system is uninterested in that fact, even though the presence of the Form A restriction renders it particularly important for it to be clear that the registered proprietors are behaving properly. Of course, the current limitations on the registrar's interest are consistent with the express statutory statement that ' $\mathrm{t}$ ] he registrar shall not be affected with notice of a trust.' ${ }^{103}$ It might also be said that, where the surviving co-owners are content to sell the property over the heads of the estate beneficiaries, that indicates a level of animosity such that an application under the Trusts of Land and Appointment of Trustees Act 1996 will be inevitable, ${ }^{104}$ and that such an application is likely to produce a sale in any event by virtue of the courts' usual preference. ${ }^{105}$ But a court application would at least allow the beneficiary properly to put the case for retention of the property, and a court-ordered sale might reduce the risk that the sale proceeds will be dissipated and therefore rendered unavailable to the beneficiary. This is another situation where prevention is better than cure.

In the perhaps more usual situation where there is only one remaining trustee (such as a surviving spouse) once a co-owner has died, the Form A restriction will not be cancelled automatically and will catch any attempted disposition unless another trustee is appointed. ${ }^{106}$ This at least gives the personal representative an opportunity to become involved in a transaction if he becomes a legal owner (or to block it if no other legal owner can be found). The Land Registry's Practice Guide nevertheless expressly states that even where a Form A restriction has not been automatically cancelled, 'consideration should be given to applying to cancel any existing Form A restriction', even if only where 'following the death of a joint proprietor a sole surviving proprietor has become the sole beneficial owner.'107 The Guide actively advises that 'applying to cancel the restriction at the earliest opportunity may avoid problems arising on a future disposition when the necessary evidence is no longer readily available. ${ }^{108}$ The application would be made on Form RX3, 'accompanied by evidence of the

${ }^{102}$ G Owen and D Cahill, 'Overreaching - Getting the Right Balance' [2017] Conv 26, 33.

${ }^{103}$ Land Registration Act 2002, s 78 .

${ }^{104}$ Trusts of Land and Appointment of Trustees Act 1996, ss 14-15.

${ }^{105}$ M Dixon, 'To Sell or not to Sell: That is the Question - The Irony of the Trusts of Land and Appointment of Trustees Act 1996' (2011) 70 CLJ 579.

${ }^{106}$ HM Land Registry (n 29 above) [6].

107 ibid.

${ }^{108}$ ibid. 
equitable title to show that the sole survivor has become the sole beneficial owner. ${ }^{109}$ The evidence 'usually' accepted is:

a statutory declaration or statement of truth ... by the sole surviving proprietor which shows how they have become the sole beneficial owner by:

- explaining what has happened to the beneficial interest protected by the restriction

- if it has devolved to the surviving proprietor, explaining how this happened

- confirming, if it is true, that no one other than the registered proprietor now has a beneficial interest in the property

- confirming, if it is true, that no beneficial interest in the property has been separately mortgaged or charged, and that no beneficial owner is or was subject to a charging order or bankruptcy proceedings (a registered mortgage does not count). ${ }^{110}$

The Land Registry confirms that

[i]nstead of a statutory declaration or statement of truth, we will accept a certificate to [the] effect [of the evidence above] from the conveyancer acting for the surviving proprietor if they are able to speak from personal knowledge of the facts,

or 'a court order requiring the registrar to cancel the restriction may be lodged.' ${ }^{111}$

It is noteworthy that there is no necessary consideration of the will or intestacy rules themselves in this procedure, which would demonstrate the fact (if true) that the surviving co-owner is actually beneficially entitled to the whole property despite the fact that it was previously subject to a tenancy in common. This is consistent with the express negation of the Land Registry having a duty to enquire into the will, highlighted in the case of sole ownership above. It nevertheless seems odd to rely on the surviving co-owner's word rather than the documentary evidence actually establishing entitlement, or indeed to rely on the word of someone other than the personal representatives, whose duty it is to investigate the full facts and ensure that the will and/or the intestacy rules are properly implemented. Although it would be a dangerous strategy for a surviving co-owner to misrepresent the terms of a will (itself not immune from forgery) ${ }^{112}$ in light of its status as a public document, this is a possibility and the Law Society and Land Registry have noted the existence of 'intra-family frauds that are perpetrated by family members, friends or partners. ${ }^{113}$ In particular, the fact that the Land Registry does not even require a grant of representation as evidence in these cases means that there are circumstances (when no other assets in the estate require a grant) where a co-owner may entirely conceal the existence of a will disposing of the property to other (true) beneficiaries, whereas the registration of the death itself is obligatory. ${ }^{114}$

There is also the issue that the verification process applies only where the surviving co-owner is seeking to cancel the restriction. If the sole surviving owner were to appoint another trustee with whom he was in cahoots (perhaps a new partner), he could formally

\footnotetext{
${ }^{109}$ ibid [7].

${ }^{110}$ ibid.

111 ibid.

${ }^{112}$ See, eg, In re the Estate of Patel [2017] EWHC 133 (Ch).

${ }^{113}$ HM Land Registry and Law Society (n 45 above) 6.

${ }^{114}$ Births and Deaths Registration Act 1953, Part II.
} 
comply with the restriction and more easily circumvent the terms of the will or the intestacy rules. In such circumstances a survivor could (legitimately under the current law) avoid even obtaining a grant of probate where all the other significant assets ${ }^{115}$ in the estate are co-owned.

The next section considers some potential solutions to the problems identified in this chapter.

\section{Possible Solutions}

If there are thought to be problems with the law's approach to registered land (whether previously co-owned or not) following a death, what might be the solutions?

One possibility would be to require personal representatives to be registered as legal owners. This would be consistent with the general rule that the legal title to the deceased's assets vests in personal representatives on death and places the personal representative in a better position to perform their duties towards the beneficiaries, even if it is not consistent with the general law's approach to trusts per se where there remains a surviving trustee. It could be argued that land is very important, that trusts and co-ownership are particularly common in relation to land, that trustees of residential land are also likely to be beneficiaries, and that these factors justify a distinctive approach to co-owned land. Such an approach is arguably already reflected in the distinctive requirements for overreaching imposed in relation to land. ${ }^{116}$ The requirement of registration of the personal representatives would also be less radical than (for example) requiring the consent of the beneficiary to the disposition of the property in all instances, and would thus protect dynamic security to some extent. That said, while the fiduciary and other duties owed by a personal representative are potentially more likely to be performed where the personal representative is a professional third party such as a solicitor, the beneficiary's position is unlikely to be improved significantly where the personal representative is also a surviving co-owner (such as a spouse) intent on selling the property against the interests or wishes of an estate beneficiary.

A compromise falling short of the requirement of registration of the personal representatives would be the ability, once the death has been registered but well before the issue of the grant of representation, for the personal representative to send the death certificate to the Land Registry and apply for a standard form restriction to be entered on the register. This restriction would purport to prevent anybody other than the personal representatives named on the eventual grant from disposing of the property (whether by sale or assent). A possible wording might be:

No disposition of the registered estate shall be registered unless accompanied by a Grant of Representation appointing personal representatives to administer the estate of [insert name of deceased], and the disposition is made by those personal representatives named in the Grant.

\footnotetext{
${ }^{115}$ See also, eg, Administration of Estates (Small Payments) Act 1965.

${ }^{116}$ See generally, D Fox, 'Overreaching' in P Birks and A Pretto (eds), Breach of Trust (Oxford, Hart Publishing, 2002).
} 
A variation would be to use a Form $\mathrm{Q}$ restriction, requiring consent of the personal representative(s), but allow it to be sought upon production of a death certificate and before a grant of representation.

This standard form restriction proposal would reflect the system adopted by banks, investment companies and most other financial institutions, ${ }^{117}$ and so logically it should be available for land. If such a step became an industry standard within estate administration, solicitors' firms who fail to protect the estate's interests in the land in this way could be liable in negligence and the loss covered by their indemnity insurance, therefore perhaps increasing the options for beneficiaries in seeking a remedy. The proposal would be a compromise between preventing fraud and reflecting the fact that the personal representative does not yet have authority to deal with the land. Obligations to enter restrictions are not unknown to the land registration system, as shown by the joint proprietorship obligation discussed in the previous section of this chapter. ${ }^{118}$ If an obligation is thought inappropriate, this may be a situation where the registrar should exercise his power to enter a restriction that is 'necessary or desirable' for the purpose of 'preventing invalidity or unlawfulness in relation to dispositions of a registered estate or charge.'119

A personal representative is not himself immune from impersonation, and the Law Society and Land Registry specifically recognised 'a personal representative responsible for a property where the owner has died and the property is to be sold' as a vulnerable client for these purposes. ${ }^{120}$ That said, if a restriction were entered from the moment a death certificate is received, requiring production of the grant of probate or letters of administration before the land can be dealt with, the true personal representative will have little trouble in transferring the land to either true beneficiaries or legitimate purchasers. The land will in all likelihood be used by those truly entitled and the risk of fraud is reduced.

One further step could be to include the Land Registry within the Government's 'Tell Us Once' system. ${ }^{121}$ When registering a death, the informant can (with the help of the registrar of births and deaths) complete a short application such that 'parts of the DWP and other organisations such as HMRC, Local Authorities' Family Information Services and Library Services' are essentially automatically informed of the death. ${ }^{122}$ It would not be unrealistic for the Land Registry also to be informed under this scheme, and a notice or restriction then automatically entered on each title for which the deceased is a registered proprietor. This would serve the desirable objective of an up-to-date register.

As regards previously co-owned land held on trust, one possibility might be to pull back the 'curtain' and allow the substantive registration of trust interests (or their protection by notice), which creates the potential for the true nature of interests under trusts ${ }^{123}$ to be reflected on the register. ${ }^{124}$ In addition to the potential for greater protection for the interests concerned, this would also be consistent with the drive towards transparency in

\footnotetext{
${ }^{117}$ See, eg, Law Society et al (n 79 above).

${ }^{118}$ Land Registration Act 2002, s 44(1).

${ }^{119}$ Land Registration Act 2002, s 42(1)(a).

${ }^{120}$ HM Land Registry and Law Society (n 45 above) 9.

${ }^{121}$ Welfare Reform Act 2012, s 135, inserting Registration Service Act 1953, s 19A; Gov.uk, 'What to do after Someone Dies: Tell Us Once', www.gov.uk/after-a-death/organisations-you-need-to-contact-and-tell-us-once.

${ }^{122}$ Explanatory Notes to the Welfare Reform Act 2012 [692].

${ }^{123}$ Implied, resulting and constructive trusts aside.

${ }^{124}$ See, eg, Owen and Cahill (n 102 above) 37-40.
} 
trust interests. ${ }^{125}$ The effect of a registration requirement would be limited, however, by the fact that an estate beneficiary does not acquire a fully-fledged proprietary interest in the estate assets until the process of estate administration is complete (unless he was previously an inter vivos trust beneficiary), ${ }^{126}$ although the equity to compel due administration of the estate may currently be protectable by notice. ${ }^{127}$ Registration of a beneficiary's interest would in any case require accurate information to be made available in the first place to would-be trust beneficiaries following a death.

Finally, it could be possible to require the Land Registry to examine the grant of probate or of letters of administration, together with any will and trust document and having appropriately verified relevant identities. Such evidence could be scrutinised in any circumstance where surviving co-owner(s) are claiming that no one other than themselves is beneficially entitled following a death, at least in circumstances where there is reason to believe that the property was held subject to a tenancy in common rather than a joint tenancy by the time of the death. This suggestion would involve more substantive examination of trust terms than is currently the case, but is arguably simply a stronger form of evidence than is currently required for the Registry's existing verification processes.

\section{Conclusion}

We have demonstrated that in both sole- and co-owner situations the current law and practice place greater emphasis on the importance of the conclusiveness of the land register than on the need to protect the rights of true testamentary or intestacy beneficiaries in the context of registered land, in some cases placing the land registration system at odds with the general law, logic and normative principle. This sidelining of testamentary freedom becomes more acute in the current climate where sophisticated property fraud is on the rise, and the lack of simple protective mechanisms could easily result in the true beneficiary losing out.

On the orthodox account, the current land registration system's focus is to protect the innocent third-party purchaser, but Cooper has said that 'a fixed purchaser protection rule ... might perversely take the land from a party who cherishes its uniqueness in order to reallocate it to a party who regards it only as a characterless repository of wealth. ${ }^{128}$ Such an approach would be in clear tension with succession law's principles of testamentary freedom and passing on property as a home to loved ones. While testamentary freedom is not and should not be an absolute principle, it should be qualified through transparent and lawful mechanisms rather than the possibility of fraud and breach of trust. Although innocent purchasers must of course be offered security, and although the judiciary have found ways

\footnotetext{
${ }^{125}$ See the debates (discussed ibid) surrounding Directive 2015/849 on the prevention of the use of the financial system for the purpose of money laundering or terrorist funding, amending Regulation 648/2012 and repealing Directive 2005/60 and Commission Directive 2006/70 [2015] OJ L141/73. cf F Noseda, 'For or Against the Registration of Trusts - Why it Matters: Balancing Regulatory Concerns and the Right to Privacy' [2014] Private Client Business 137 and Evans (n 41 above).

${ }^{126}$ Commissioner of Stamp Duties (Queensland) v Livingston [1965] AC 694 (PC).

${ }^{127}$ Land Registration Act 2002, s 115; cfs 33.

${ }^{128}$ Cooper (n 20 above) 131.
} 
to reduce innocent purchaser protection where arguably appropriate, ${ }^{129}$ perhaps Owen and Cahill have a point when they say that 'the scales need resetting' when balancing overreaching with beneficial interests that can be applied to the succession context. ${ }^{130}$

The ease with which beneficial ownership can prima facie be extinguished on the land register adds to this tension. The most recent Land Registration Act is now 17 years old, and the blasé attitude shown by the Act towards beneficial interests is perhaps starting to look outdated in the current climate of transparency propounded by recent anti-money laundering legislation, and advocated directly in the land registration context by Owen and Cahill. Furthermore, as Ferris puts it: 'Land registration cannot be reduced to the single objective of lowering transaction costs at the cost of static security and principles of justice. The system has a fundamental interest in the protection of static security.' ${ }^{131}$

Whilst the Money Laundering Regulations have tightened up the identification requirements for conveyancers, the Law Commission has proposed reforms to identity verification and the Land Registration Act 2002 provides mechanisms for rectification and indemnity in the case where a true owner or chargee has lost out due to fraud, there is surely a case for introducing a simple preventative mechanism such as the entry of a restriction on the register on production of a death certificate to reduce the ease with which fraud can be perpetrated. This must be preferable to the protracted and upsetting process of untangling the mess once it has happened. Given the huge monetary and societal value placed on land, most of our suggestions do not seek fundamentally to change the nature of land registration, but rather to assist the land registration system to provide a just, rather than merely a procedurally correct, outcome. Our proposals would also have the by-product of increasing the accuracy of the register, and thus help to reduce the tension between testamentary freedom and dynamic security identified in this chapter.

\footnotetext{
${ }^{129}$ See, eg, Goymour (n 12 above).

${ }^{130}$ Owen and Cahill (n 102 above).

${ }^{131}$ Ferris (n 76 above) 234.
} 